\title{
Nutrient requirements for growth of the extreme oligotroph 'Candidatus Pelagibacter ubique' HTCC1062 on a defined medium
}

\author{
Paul Carini, Laura Steindler ${ }^{1}$, Sara Beszteri ${ }^{2}$ and Stephen J Giovannoni \\ Department of Microbiology, Oregon State University, Corvallis, OR, USA
}

\begin{abstract}
Chemoheterotrophic marine bacteria of the SAR11 clade are Earth's most abundant organisms. Following the first cultivation of a SAR11 bacterium, 'Candidatus Pelagibacter ubique' strain HTCC1062 (Ca. P. ubique) in 2002, unusual nutritional requirements were identified for reduced sulfur compounds and glycine or serine. These requirements were linked to genome streamlining resulting from selection for efficient resource utilization in nutrient-limited ocean habitats. Here we report the first successful cultivation of $\mathrm{Ca}$. P. ubique on a defined artificial seawater medium (AMS1), and an additional requirement for pyruvate or pyruvate precursors. Optimal growth was observed with the collective addition of inorganic macro- and micronutrients, vitamins, methionine, glycine and pyruvate. Methionine served as the sole sulfur source but methionine and glycine were not sufficient to support growth. Optimal cell yields were obtained when the stoichiometry between glycine and pyruvate was 1:4, and incomplete cell division was observed in cultures starved for pyruvate. Glucose and oxaloacetate could fully replace pyruvate, but not acetate, taurine or a variety of tricarboxylic acid cycle intermediates. Moreover, both glycine betaine and serine could substitute for glycine. Interestingly, glycolate partially restored growth in the absence of glycine. We propose that this is the result of the use of glycolate, a product of phytoplankton metabolism, as both a carbon source for respiration and as a precursor to glycine. These findings are important because they provide support for the hypothesis that some micro-organisms are challenging to cultivate because of unusual nutrient requirements caused by streamlining selection and gene loss. Our findings also illustrate unusual metabolic rearrangements that adapt these cells to extreme oligotrophy, and underscore the challenge of reconstructing metabolism from genome sequences in organisms that have non-canonical metabolic pathways.
\end{abstract}

The ISME Journal (2013) 7, 592-602; doi:10.1038/ismej.2012.122; published online 25 October 2012

Subject Category: microbial ecology and functional diversity of natural habitats

Keywords: alanine; genome streamlining; glycolate; phytoplankton

\section{Introduction}

Laboratory studies of ecologically important organisms are important for understanding the principles and mechanisms that govern ecosystem behavior (Giovannoni and Stingl, 2007). For example, several studies have reported high connectedness in marine plankton communities (Fuhrman et al., 2006; Steele et al., 2011). 'Connectance' is a general measure of the degree to which populations within a community display correlated behavior, and, in terrestrial ecosystems, has been linked to ecosystem stability

Correspondence: SJ Giovannoni, Department of Microbiology, Oregon State University, 220 Nash Hall, Corvallis, OR 97331, USA.

E-mail: steve.giovannoni@oregonstate.edu

${ }^{1}$ Current address: Department of Marine Biology, The Leon $\mathrm{H}$ Charney School of Marine Science, University of Haifa, Haifa, Israel

${ }^{2}$ Current address: Alfred Wegener Institute for Polar and Marine Research, Bremerhaven, Germany

Received 3 April 2012; revised 21 August 2012; accepted 27 August 2012; published online 25 October 2012
(Dunne et al., 2002). The SAR11 clade of $\alpha$-proteobacteria are the most abundant heterotrophs in marine euphotic zones worldwide (Morris et al., 2002), and have been shown to contribute significantly to the overall connectedness of marine microbial plankton communities (Steele et al., 2011). Specific mechanisms that might explain SAR11 connectedness are slowly emerging from studies of genomes and the metabolism of cells in culture (Tripp et al., 2008; 2009; Schwalbach et al., 2010; Sun et al., 2011).

'Candidatus Pelagibacter ubique' HTCC1062 (Ca. P. ubique), a member of the SAR11 clade, has a small genome and displays characteristic signatures of streamlining selection (Giovannoni et al., 2005). According to the genome streamlining theory, when effective population sizes are large, extreme selection for the efficient use of resources in nutrient-poor environments can result in genome reduction (Dufresne et al., 2003; Lynch and Conery, 2003; Giovannoni et al., 2005). The metabolic consequences of genome reduction in $\mathrm{Ca}$. P. ubique 
have been the subject of several reports (Tripp et al., 2008, 2009; Schwalbach et al., 2010).

Metabolic reconstruction from the $C a$. P. ubique genome highlighted the conspicuous absence of genes common to aerobic chemoorganoheterotrophs (Figure 1). Subsequent batch culture experiments, using a natural seawater medium, showed that $C a$. P. ubique required an unusual combination of nutrients for growth (Tripp et al., 2008, 2009; Schwalbach et al., 2010). Specifically, Ca. P. ubique lacks genes necessary for assimilatory sulfate reduction, and as a result, requires reduced sulfur compounds such as methionine or 3-dimethylsulphoniopropionate for growth (Tripp et al., 2008). Similarly, the unusual absence of common genes for serine and glycine biosynthesis resulted in a conditional requirement for either of these amino acids (Tripp et al., 2009). Concomitantly, an uncommon arrangement of two glycine-activated riboswitches was reported; one

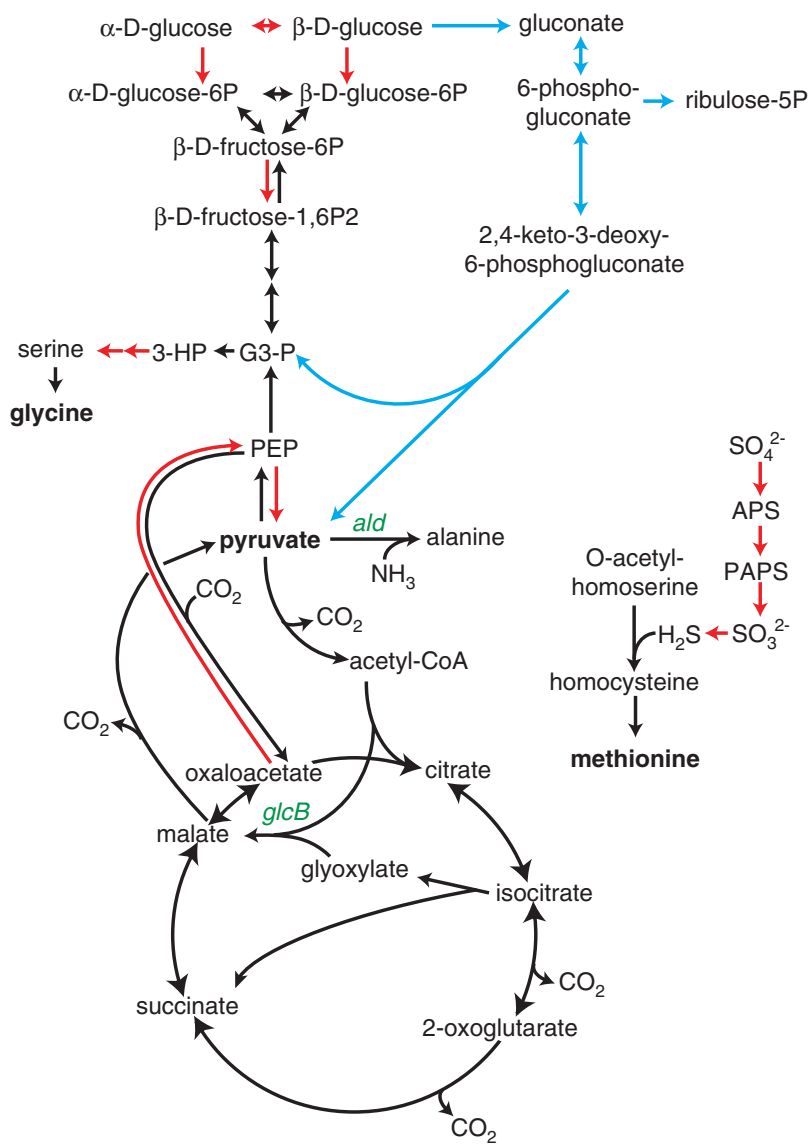

Figure 1 Simplified illustration of central metabolism in Ca. P. ubique. Black lines: reactions predicted to occur in $\mathrm{Ca}$. P. ubique based on genome content. Red lines: reactions predicted to occur in E. coli, but missing from $\mathrm{Ca}$. P. ubique. Blue lines: putative glucose oxidation pathway (see Schwalbach et al., 2010). Gene names in green are discussed further in the article. Bolded compounds were previously identified as growth substrates for $C a$. P. ubique. ald, alanine dehydrogenase; $g l_{C B}$, malate synthase; APS, adenosine 5'-phosphosulfate; G3-P, glyceraldehyde-3-phosphate; 3-HP, 3-hydroxypyruvate; PAPS: 3'-phosphoadenylyl sulfate, PEP: phosphoenolpyruvate. located upstream of the gene encoding for the glycine cleavage system T-protein $\left(g_{C V} T\right)$ and the other upstream of the malate synthase gene $\left(g l_{c} B\right)$ (Tripp et al., 2009). The first of these is a common riboswitch involved in glycine cleavage to $\mathrm{CO}_{2}$ and $\mathrm{NH}_{4}^{+}$, but the second is a rare riboswitch configuration that was implicated in glyoxylate metabolism (Tripp et al., 2009). Although Ca. P. ubique is missing the complete Embden-Meyerhof-Parnas glycolytic pathway (genes encoding pyruvate kinase and phosphofructokinase are absent, Figure 1), a putative operon encoding genes involved in a predicted variant of the Entner-Doudoroff glycolytic pathway is present, as is a complete gluconeogenic pathway (Figure 1; Schwalbach et al., 2010). Experiments showed that low molecular weight organic acids were important carbon sources for multiple SAR11 isolates and that $C a$. P. ubique, but not all SAR11 isolates, oxidized glucose (Schwalbach et al., 2010). Moreover, genes coding for proteins involved in carbohydrate metabolism are not consistently conserved across the SAR11 clade, suggesting that the metabolism of sugars and other carbohydrates may be involved in niche partitioning or ecotype variation (Grote et al., 2012).

Previously, Ca. P. ubique was grown exclusively in natural seawater-based media. However, seawater contains an undefined mixture of naturally occurring organic compounds that vary in composition and quantity between seasons, locations and depths. The consequences of this nutrient variability on $C a$. P. ubique's physiology was initially observed in the form of 'batch effects', in which seawater collected at different times yielded different cell densities or growth rates independent of nutrient additions (Rappé et al., 2002). The three main limitations of conducting experiments with $\mathrm{Ca}$. P. ubique cells on natural seawater-based media are: (i) the precise composition and concentrations of organic matter in seawater is unknown and variable; (ii) the finite supply of any single seawater batch limits comparisons between experiments conducted with different batches; and (iii) native concentrations of nutrients (for example, nitrogen, sulfur and carbon) cannot be excluded.

We developed a defined medium to use as a tool for studying the nutrient requirements and metabolism of $C a$. P. ubique. Ultimately, without a defined medium, it was impossible to rule out that unknown compounds in natural organic matter were essential for growth of $C a$. P. ubique. A simple approach to solve this problem is the addition of a diverse mixture of compounds, under the assumption that the organism will use only what it needs. This approach is commonly implemented by adding mixtures of nutrients such as yeast extract or digests of protein to growth media. However, complex, high-nutrient mixtures inhibit the growth of many oligotrophic chemoheterotrophs, making this strategy impractical (Rappé et al., 2002; Tripp et al., 2008, 2009). Building on previous metabolic models for 
Ca. P. ubique, we hypothesized that the minimum nutrient requirements for growth on a defined medium would include pyruvate in addition to a source of reduced sulfur and glycine. We report here the propagation of $C a$. P. ubique to high cell density on a defined artificial seawater medium containing inorganic micro- and macronutrients, vitamins, methionine (for reduced sulfur), glycine and pyruvate. Pyruvate, or its precursors, was identified as the last essential macronutrient needed by $C a$. P. ubique for growth. We also demonstrate that several environmentally relevant compounds can be used by $C a$. P. ubique in place of pyruvate and glycine, and describe unusual rearrangements of central metabolic pathways that confer these properties.

\section{Materials and methods}

\section{Organism source}

Ca. P. ubique HTCC1062 was originally isolated from the northeast Pacific Ocean as described elsewhere (Rappé et al., 2002). Frozen glycerol stocks from the original isolation of $C a$. P. ubique were used as the source inoculum for all experiments.

\section{Media preparation}

Artificial seawater medium AMS1 (Table 1) was derived from the artificial seawater medium AMP1 (Moore et al., 2007). Organic buffers (for example, HEPES and EDTA) were excluded to avoid potential toxic effects (Zigler et al., 1985) and the possibility that they might be used as substrates for growth (Nörtemann, 1992). After autoclaving, AMS1 was sparged with $0.1 \mu \mathrm{m}$-filtered $\mathrm{CO}_{2}$ for $5 \mathrm{~h}$ followed by sparging with air for $10 \mathrm{~h}$ to establish a bicarbonatebased buffer system (Connon and Giovannoni, 2002). All vitamins and organics were added after autoclaving and sparging. The $\mathrm{pH}$ of the resulting AMS1 typically ranged from 7.5 to 7.7 .

\section{Cultivation details}

All cultures were grown in acid-washed and autoclaved polycarbonate flasks at $20^{\circ} \mathrm{C}$ with shaking at 60 r.p.m. under a 12-h/12-h light $(140-180 \mu \mathrm{mol}$ photons $\mathrm{m}^{-2} \mathrm{~s}^{-1}$ )/dark cycle.

\section{Measurement of growth}

Cells were stained with SYBR Green I (Molecular Probes, Inc., Eugene, OR, USA) and counted with a Guava Technologies flow cytometer (Millipore, Billerica, MA, USA) at 48- to 72-h intervals as described elsewhere (Stingl et al., 2007; Tripp et al., 2008).

\section{Acclimation to growth on AMS1}

Natural seawater collected from the Newport Hydroline station NH-05 (latitude: $44.65^{\circ}$, longitude:
Table 1 Constituents of the artificial medium for SAR11 (AMS1)

\begin{tabular}{|c|c|}
\hline Compound & Final concentration \\
\hline \multicolumn{2}{|l|}{ Base salts } \\
\hline $\mathrm{NaCl}$ & $481 \mathrm{~mm}$ \\
\hline $\mathrm{MgCl}_{2} \cdot 6 \mathrm{H}_{2} \mathrm{O}$ & $27 \mathrm{~mm}$ \\
\hline $\mathrm{CaCl}_{2} \cdot 2 \mathrm{H}_{2} \mathrm{O}$ & $10 \mathrm{~mm}$ \\
\hline $\mathrm{KCl}$ & $9 \mathrm{~mm}$ \\
\hline $\mathrm{NaHCO}_{3}$ & $6 \mathrm{~mm}$ \\
\hline $\mathrm{MgSO}_{4} \cdot 7 \mathrm{H}_{2} \mathrm{O}$ & $2.8 \mathrm{~mm}$ \\
\hline \multicolumn{2}{|l|}{ Macronutrients } \\
\hline$\left(\mathrm{NH}_{4}\right)_{2} \mathrm{SO}_{4}$ & $400 \mu \mathrm{M}$ \\
\hline $\mathrm{NaH}_{2} \mathrm{PO}_{4}(\mathrm{pH} 7.5)$ & $50 \mu \mathrm{M}$ \\
\hline \multicolumn{2}{|l|}{ Trace metals } \\
\hline $\mathrm{FeCl}_{3} \cdot 6 \mathrm{H}_{2} \mathrm{O}$ & $117 \mathrm{~nm}$ \\
\hline $\mathrm{MnCl}_{2} \cdot 4 \mathrm{H}_{2} \mathrm{O}$ & $9 \mathrm{nM}$ \\
\hline $\mathrm{ZnSO}_{4} \cdot 7 \mathrm{H}_{2} \mathrm{O}$ & $800 \mathrm{pM}$ \\
\hline $\mathrm{CoCl}_{2} \cdot 6 \mathrm{H}_{2} \mathrm{O}$ & $500 \mathrm{pM}$ \\
\hline $\mathrm{Na}_{2} \mathrm{MoO}_{4} \cdot 2 \mathrm{H}_{2} \mathrm{O}$ & $300 \mathrm{pM}$ \\
\hline $\mathrm{Na}_{2} \mathrm{SeO}_{3}$ & $1 \mathrm{nM}$ \\
\hline $\mathrm{NiCl}_{2} \cdot 6 \mathrm{H}_{2} \mathrm{O}$ & $1 \mathrm{~nm}$ \\
\hline \multicolumn{2}{|l|}{ Vitamins } \\
\hline $\mathrm{B}_{1}$ & $6 \mu \mathrm{M}$ \\
\hline $\mathrm{B}_{3}$ & $800 \mathrm{~nm}$ \\
\hline $\mathrm{B}_{5}$ & $425 \mathrm{~nm}$ \\
\hline $\mathrm{B}_{6}$ & $500 \mathrm{~nm}$ \\
\hline $\mathrm{B}_{7}$ & $4 \mathrm{~nm}$ \\
\hline$B_{9}$ & $4 \mathrm{nM}$ \\
\hline $\mathrm{B}_{12}$ & $700 \mathrm{pM}$ \\
\hline Myo-inositol & $6 \mu \mathrm{M}$ \\
\hline 4-Aminobenzoic acid & $60 \mathrm{~nm}$ \\
\hline
\end{tabular}

aThe AMS1 medium does not include nutrients to meet the requirements for reduced sulfur (see Tripp et al., 2008), glycine (see text) or pyruvate (see text).

$-124.18^{\circ}$ ) from a depth of $10 \mathrm{~m}$ in June 2008 was amended with glycine $(1 \mu \mathrm{M})$, methionine $(1 \mu \mathrm{M})$, pyruvate $(50 \mu \mathrm{M}), \mathrm{FeCl}_{3}(1 \mu \mathrm{M})$ and vitamins and inoculated with $\mathrm{Ca}$. P. ubique from glycerol stocks. When exponentially growing cells in this amended natural seawater medium exceeded a density of $2.0 \times 10^{6}$ cells ml $^{-1}$, they were diluted (1:100) with fresh AMS1 supplemented with glycine $(1 \mu \mathrm{M})$ (as a glycine/serine source), methionine (as a sulfur source) $(1 \mu \mathrm{M})$, pyruvate (as a carbon source) $(50 \mu \mathrm{M}), \mathrm{FeCl}_{3}(1 \mu \mathrm{M})$ and vitamins. We observed no lag phase in cells that were transferred into amended AMS1 (Supplementary Figure S1). All cultures described herein are derived from this lineage and have been maintained exclusively on AMS1 for $>15$ consecutive batch culture transfers (approximately 150 generations).

Pyruvate substitution experiments

Potential pyruvate precursors (Table 2) were selected because they were either (i) 'common' sole carbon sources for chemoorganoheterotrophs or (ii) present in seawater as products of phytoplankton metabolism. Each substitute was tested at a concentration of $50 \mu \mathrm{M}$ in AMS1 amended with $25 \mu \mathrm{M}$ 
glycine, $10 \mu \mathrm{M}$ methionine, $1 \mu \mathrm{M} \mathrm{FeCl}_{3}$ and vitamins. The positive control was amended with $50 \mu \mathrm{M}$ pyruvate and the same concentrations of glycine, methionine, $\mathrm{FeCl}_{3}$ and vitamins. The negative control contained no pyruvate, but was otherwise identical.

\section{Glycine substitution experiments}

Potential glycine precursors (Table 3) were selected because they were either (i) metabolic precursors of glycine in other organisms or (ii) predicted to be a precursor based on metabolic reconstruction in $C a$. P. ubique. Each substitute was tested at a concentration of $25 \mu \mathrm{M}$ in AMS1 with pyruvate $(50 \mu \mathrm{M})$, methionine $(10 \mu \mathrm{M}), \mathrm{FeCl}_{3}(1 \mu \mathrm{M})$ and vitamins. The positive control was amended with $25 \mu \mathrm{M}$ glycine and the negative control contained no glycine.

\section{Cell division experiments}

Growth media consisted of AMS1 amended with glycine $(1 \mu \mathrm{M})$, methionine $(1 \mu \mathrm{M}), \mathrm{FeCl}_{3}(1 \mu \mathrm{M})$,

Table 2 Potential sources of pyruvate for $C a$. P. ubique when grown in AMS1 with $25 \mu \mathrm{m}$ glycine and $10 \mu \mathrm{m}$ methionine

\begin{tabular}{lcc}
\hline Potential pyruvate source & Maximum density & Growth rate \\
\hline Glucose & $12.1 \pm 3.83$ & $0.27 \pm 0.02$ \\
Pyruvate (positive control) & $8.91 \pm 0.74$ & $0.33 \pm 0.01$ \\
Oxaloacetate & $6.92 \pm 0.04$ & $0.33 \pm 0.04$ \\
Taurine & $0.46 \pm 0.14$ & $0.21 \pm 0.02$ \\
Lactate & $0.11 \pm 0.09$ & $0.18 \pm 0.04$ \\
Ribose & $0.05 \pm 0.01$ & $0.23 \pm 0.01$ \\
Malate & $0.03 \pm 0.01$ & $0.14 \pm 0.04$ \\
Citrate & $0.03 \pm 0.00$ & $0.12 \pm 0.01$ \\
Acetate & $0.02 \pm 0.01$ & $0.10 \pm 0.05$ \\
No pyruvate (negative control) & $0.02 \pm 0.01$ & $0.13 \pm 0.02$ \\
Succinate & $0.02 \pm 0.00$ & $0.11 \pm 0.01$ \\
Alanine & $0.01 \pm 0.00$ & $0.01 \pm 0.01$ \\
Glycine & $0.01 \pm 0.00$ & $0.06 \pm 0.01$ \\
\end{tabular}

aPresented as mean \pm s.d. $\times 10^{7}$ cells $\mathrm{ml}^{-1}, n=3$.

bPresented as mean \pm s.d., cells day ${ }^{-1}, n=3$.

Table 3 Potential sources of glycine for Ca. P. ubique when grown in AMS1 with $50 \mu \mathrm{m}$ pyruvate and $10 \mu \mathrm{m}$ methionine

\begin{tabular}{lcc}
\hline Potential glycine source & Maximum density & Growth rate \\
\hline Glycine betaine & $13.1 \pm 0.34$ & $0.18 \pm 0.01$ \\
Glycine (positive control) & $10.2 \pm 0.28$ & $0.38 \pm 0.01$ \\
Serine & $8.34 \pm 0.15$ & $0.40 \pm 0.01$ \\
Glycolate & $1.88 \pm 0.13$ & $0.35 \pm 0.01$ \\
Acetate & $0.66 \pm 0.10$ & $0.30 \pm 0.01$ \\
Malate & $0.51 \pm 0.03$ & $0.32 \pm 0.03$ \\
Glyoxylate & $0.50 \pm 0.01$ & $0.38 \pm 0.01$ \\
Succinate & $0.46 \pm 0.06$ & $0.31 \pm 0.01$ \\
Pyruvate & $0.44 \pm 0.05$ & $0.35 \pm 0.01$ \\
Citrate & $0.44 \pm 0.01$ & $0.29 \pm 0.01$ \\
No glycine (negative control) & $0.43 \pm 0.02$ & $0.34 \pm 0.00$ \\
2-Oxoglutarate & $0.39 \pm 0.05$ & $0.33 \pm 0.01$
\end{tabular}

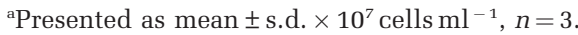

${ }^{b}$ Presented as mean \pm s.d., cells day ${ }^{-1}, n=3$. vitamins and either $0.5 \mu \mathrm{M}$ pyruvate (deplete conditions) or $50 \mu \mathrm{M}$ pyruvate (replete conditions). SYBR Green I-stained cultures that exhibited relative DNA fluorescence values of 300-325 and 475-500, were independently filtered on to $0.2 \mu \mathrm{m}$ black polycarbonate filters, and imaged using a Leica DMRB epifluorescence microscope (Wetzlar, Germany) equipped with filter sets appropriate for SYBR Green I (excitation: 450-490 nm; emission: $580 \mathrm{~nm}$ ). Images were captured with a Hamamatsu ORCA-ER CCD digital camera (Hamamatsu City, Japan) and Scanalytics IPLab v3.5.5 scientific imaging software (Fairfax, VA, USA).

\section{Chemicals}

All inorganic salts were obtained from SigmaAldrich Co. (St Louis, MO, USA) and were of the highest available quality (typically labeled 'ultrapure'). All other compounds were obtained from Sigma-Aldrich Co. or other commercial vendors and were of reagent grade quality.

\section{Results}

When grown on AMS1 with methionine, glycine and pyruvate, $\mathrm{Ca}$. P. ubique's maximum specific growth rate was $0.41 \pm 0.01$ day $^{-1}$ (mean \pm s.d., $n=3$ ), and batch cultures reached maximum cell densities of $9.18 \pm 0.02 \times 10^{7}$ cells ml $^{-1} \quad$ (mean \pm s.d., $\quad n=3$ ) (Figure 2). Additions of methionine or carbon (as pyruvate and glycine) alone did not result in increased cell densities beyond those of the negative control (Figure 2). Cell densities responded linearly to both pyruvate $\left(R^{2}=0.998\right)$ and glycine $\left(R^{2}=0.995\right)$ additions in AMS1 when other nutrients were in

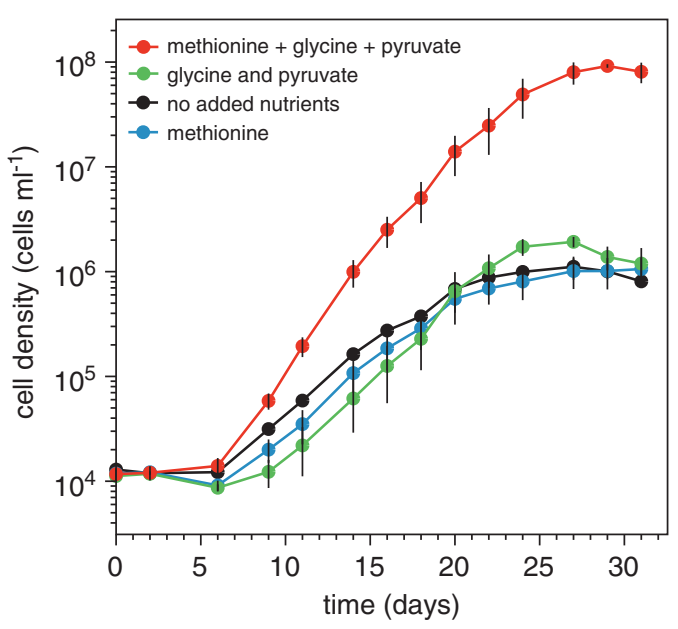

Figure 2 Growth of Ca. P. ubique in AMS1 with organic carbon additions. Black: cells grown without additions of glycine, methionine or pyruvate. Red: cells amended with methionine $(10 \mu \mathrm{M})$, glycine $(50 \mu \mathrm{M})$ and pyruvate $(50 \mu \mathrm{M})$. Blue: cells amended with methionine $(10 \mu \mathrm{M})$ only. Green: cells amended with glycine $(50 \mu \mathrm{M})$ and pyruvate $(50 \mu \mathrm{M})$ only. Points are the average density of triplicate cultures. Error bars indicate \pm 1.0 s.d. $(n=3)$. When error bars are not visible, they are smaller than the size of the symbols. 
excess (Figure 3). The maximum cell density increased by $2.6 \times 10^{6}$ cells $\mathrm{ml}^{-1} \mu \mathrm{M}^{-1}$ pyruvate (Figure 3a) and $1.0 \times 10^{7}$ cells $\mathrm{ml}^{-1} \mu \mathrm{M}^{-1}$ glycine (Figure 3b).
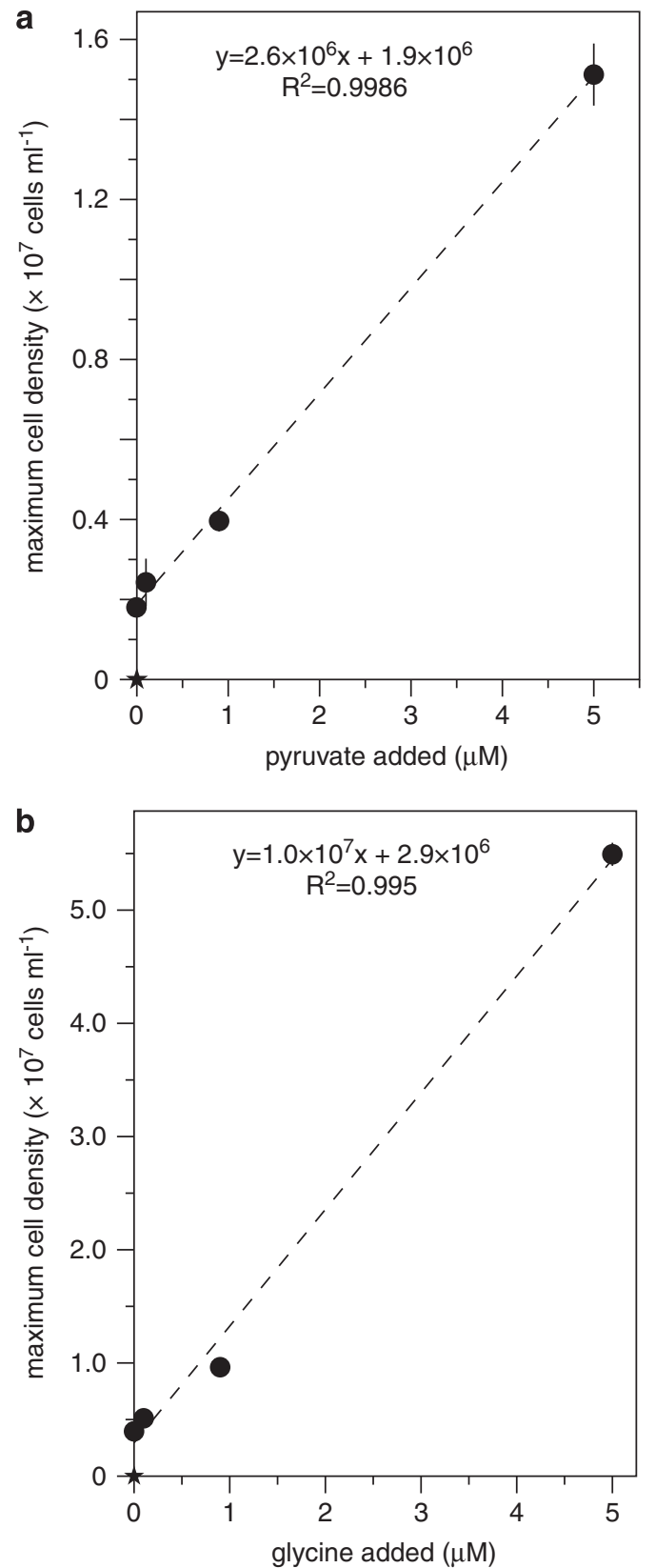

Figure 3 Maximum cell yields of $C a$. P. ubique in response to pyruvate and glycine additions. (a) Pyruvate titration in AMS1 supplemented with glycine $(50 \mu \mathrm{M})$ and methionine $(10 \mu \mathrm{M})$. Using the formula of the regression line, the maximum cell density achievable from pyruvate carryover with source inoculum $(156 \mathrm{pM})$ was calculated to be $400 \mathrm{cells} \mathrm{ml}^{-1}$ (filled star). (b) Glycine titration into AMS1 supplemented with pyruvate $(50 \mu \mathrm{M})$ and methionine $(10 \mu \mathrm{M})$. Using the formula of the regression line, the maximum cell density achievable from glycine carryover with source inoculum $(500 \mathrm{pM})$ was calculated to be 5000 cells $\mathrm{ml}^{-1}$ (filled star). Filled circles are the average maximum cell densities of triplicate batch cultures. Error bars indicate \pm 1.0 s.d. $(n=3)$. When error bars are not visible, they are smaller than the size of the symbols.
Ca. P. ubique utilized oxaloacetate and glucose in place of pyruvate on AMS1 (Table 2). As observed previously (Schwalbach et al., 2010), Ca. P. ubique's specific growth rate was slower with glucose as a sole pyruvate source. Addition of taurine or lactate resulted in cell densities in excess of fivefold greater than the negative control, but did not achieve the cell densities of the pyruvate treatment. Notably, in the absence of pyruvate, additions of alanine or glycine did not improve growth yield.

Glycine betaine and serine were able to fully replace glycine in AMS1 and glycolate partially substituted for glycine (Table 3). Ca. P. ubique grew slower but to slightly higher cell densities when glycine betaine was the sole glycine source. Glycolate led to cell density increases fourfold greater than those of the negative control. The addition of pyruvate, without glycine, did not result in higher cell densities.

While developing the AMS1 medium, unusual cell division patterns were observed under pyruvate-deplete conditions. When SYBR Green was used to stain DNA in early stationary-phase cells, fluorescence from pyruvate limited cells was about two-fold higher than from cells raised in a pyruvate-replete medium (Figures $4 \mathrm{a}$ and b). Microscopic images from these cultures showed that the increase in DNA fluorescence was caused by elongated cells containing two nucleoids ('doublets') (Figures 4c and d). We observed this unusual cell division pattern when cells entered pyruvate-limited stationary-phase across a range of pyruvate:glycine ratios (Supplementary Figure S2). This phenomenon was previously observed when $\mathrm{Ca}$. P. ubique cells were grown in a natural seawater medium without added pyruvate (unpublished data). Experiments conducted in natural seawater found alanine induced the division of cell doublets (unpublished data). The effect of different alanine concentrations on Ca. P. ubique cell morphology in stationary-phase cultures grown in AMS1 was tested using relative DNA fluorescence as a proxy for the formation of cell doublets (Supplementary Figure S3). DNA fluorescence profiles and cell counts suggested that alanine induced cell division in pyruvate-limited cultures.

\section{Discussion}

Similar to the goals of Neidhardt et al. (1974), who developed a defined medium for the growth of enterobacteria, one of our objectives was to prepare a 'physiologically optimal and experimentally useful' medium in which $\mathrm{Ca}$. P. ubique, and other SAR11 isolates, could be propagated reproducibly. This artificial medium for the growth of $C a$. P. ubique contains only methionine, glycine, pyruvate, vitamins and inorganic salts. The specific growth rates observed on AMS1 $\left(0.41 \pm 0.01\right.$ day $\left.^{-1}\right)$ were comparable to those previously published for $\mathrm{Ca}$. P. 

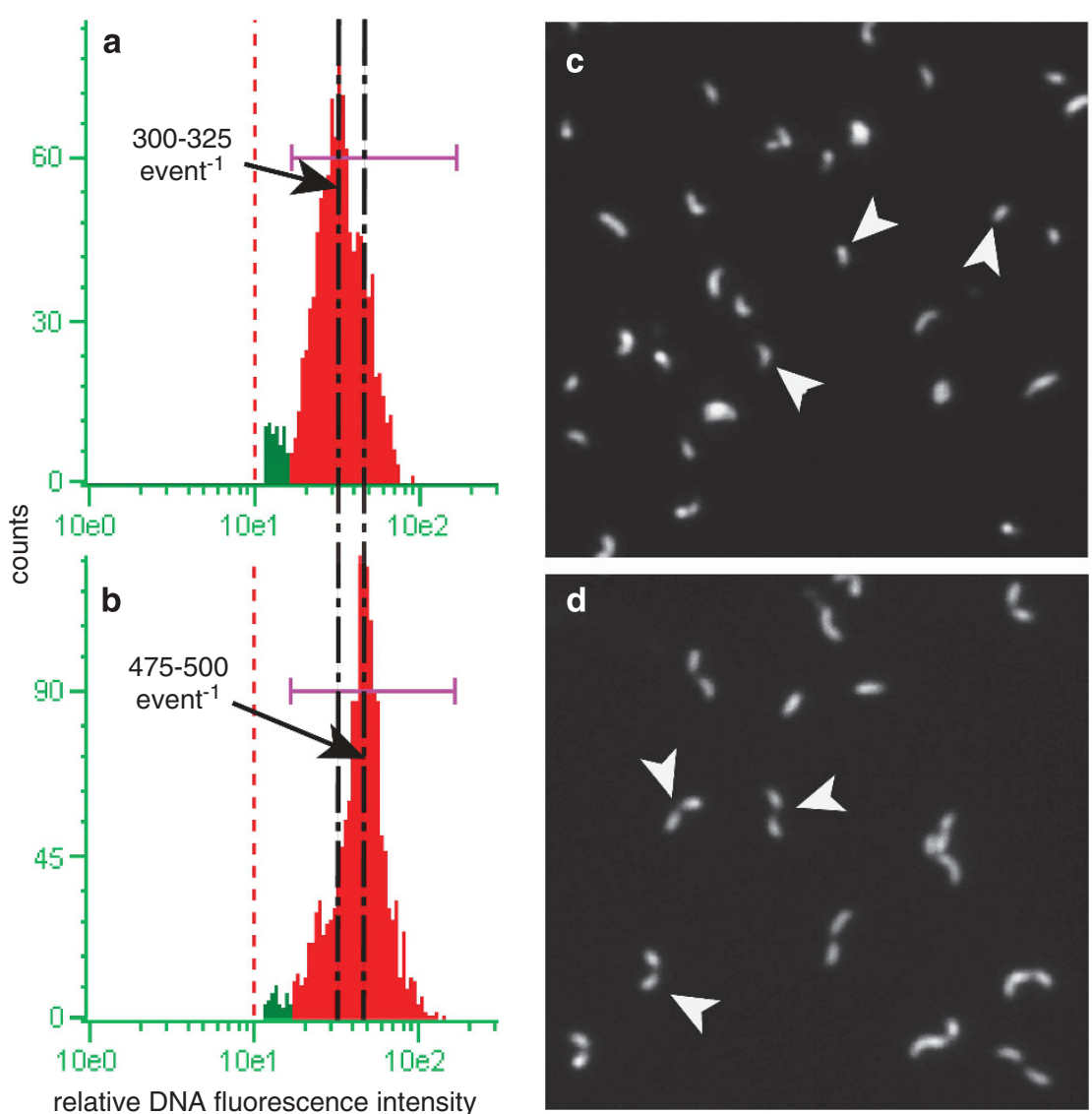

Figure 4 DNA content and morphology of SYBR Green I-stained stationary-phase cells from pyruvate-deplete and -replete batch cultures. Red dashed line in $\mathbf{a}$ and $\mathbf{b}$ represents the minimum threshold of fluorescence detection. Black dashed lines in $\mathbf{a}$ and $\mathbf{b}$ represent relative DNA fluorescence values of 300-325 per event and 475-500 per event, as indicated with black arrows. (a) Relative DNA fluorescence of cells from pyruvate-replete $(50 \mu \mathrm{M})$ stationary-phase cultures, and (b) pyruvate-deplete $(0.5 \mu \mathrm{M})$ stationary-phase cultures. (c) Fluorescent microscopy image of cells from (a). Arrowheads point to single cells. (d) Fluorescent microscopy image of cells from (b). Arrowheads point to cell doublets.

ubique grown in seawater batch cultures (Rappé et al., 2002; Tripp et al., 2008; Schwalbach et al., 2010) and to those from microcosm experiments with natural assemblages of plankton (Teira et al., 2009; Ferrera et al., 2011).

Results observed with cells growing in AMS1 support the previous conclusions that $C a$. P. ubique requires a reduced sulfur source, glycine and an organic acid for growth. Our results also confirm that methionine meets $C a$. P. ubique's requirement for exogenous reduced sulfur compounds (Tripp et al., 2008, 2009) but cannot substitute for glycine or pyruvate as a sole carbon source. The linear responses to both pyruvate and glycine additions, when other constituents were in excess, indicated that both pyruvate and glycine were necessary for optimal growth and used in the molar ratio of 4.0:1 (pyruvate:glycine). In addition, we showed that alanine is required for septation, the final step in cell division, and that in the absence of pyruvate, Ca. P. ubique cells were not able to synthesize alanine by other routes, thus implicating pyruvate as a primary precursor for alanine biosynthesis. In
Escherichia coli, the rate of cell wall biosynthesis increases during septation in order to accommodate the synthesis of the new daughter cell poles (Wientjes and Nanninga, 1989). Because alanine is a major component of cell walls in Gram-negative bacteria (Mengin-Lecreulx et al., 1982), we propose that in pyruvate-limiting conditions, Ca. P. ubique is unable to synthesize sufficient alanine to complete septation, resulting in the formation of cell doublets.

Our observations show that pyruvate or its precursors are required to synthesize alanine, but that alanine cannot replace pyruvate (Table 2). In Ca. P. ubique, L-alanine is putatively formed by an alanine dehydrogenase (encoded by ald, SAR11_0809-Figure 1). Ald catalyzes the formation of alanine from pyruvate and ammonia via the oxidation of reduced nicotinamide adenine dinucleotide, and has been shown to be involved in both the catabolism and anabolism of alanine in Pseudomonas, Rhodobacter and Sphingopyxis species (Bellion and Tan, 1987; Caballero et al., 1989; Williams et al., 2009). Although Ald catalyzes a reversible reaction in some organisms, our data suggest that in $\mathrm{Ca}$. P. ubique, Ald does not 
catalyze the formation of pyruvate from alanine under the conditions tested.

The observation that both glucose and oxaloacetate could replace pyruvate suggests that pyruvate is a metabolic intermediate formed during the catabolism of these compounds. Both compounds were previously identified as carbon sources for $C a$. P. ubique in natural seawater (Schwalbach et al., 2010). The use of oxaloacetate in place of pyruvate is consistent with the presence of a predicted malic enzyme gene (maeB, SAR11_0375) that may be involved in the decarboxylation of oxaloacetate to form pyruvate. Our results are also consistent with Schwalbach's proposed glycolytic pathway in $\mathrm{Ca}$. P. ubique that predicted pyruvate was an end product of glucose metabolism (Schwalbach et al., 2010). Previously, in natural seawater-based media, taurine, acetate and lactate additions resulted in cell density increases similar to those observed with pyruvate additions (Schwalbach et al., 2010). However, in our experiments on artificial seawater media, maximum cell densities decreased in this order: pyruvate » taurine $>$ lactate $»$ acetate (Table 2). Taurine is putatively metabolized to acetyl-CoA in Ca. P. ubique, suggesting that taurine catabolism supplies two-carbon units for biosynthesis. In our experiments, acetate, a direct precursor to acetylCoA, could not replace pyruvate (Table 2). This contradicts the prediction of a metabolic pathway for acetate assimilation as a sole carbon source via the glyoxylate bypass in Ca. P. ubique (Figure 1). We postulate that the glyoxylate bypass has instead been recruited to function in glycine metabolism, as described below.

We show for the first time that glycine betaine, in addition to serine, can meet $C a$. P. ubique's glycine requirement. Previously, Tripp et al. (2009) identified serine as the only compound able to replace glycine in natural seawater-based batch cultures of Ca. P. ubique. Consistent with this finding, we found that serine was an effective replacement for glycine on AMS1 (Table 3). Glycine betaine is an important osmolyte that can be degraded by marine bacteria (Kiene and Williams, 1998; Keller et al., 1999; Sun et al., 2011). Ca. P. ubique's genome encodes a full suite of genes predicted to be involved in the acquisition and stepwise oxidation of glycine betaine to form glycine (Tripp et al., 2009; Sun et al., 2011). Experiments also showed that Ca. P. ubique can oxidize methyl groups derived from glycine betaine to $\mathrm{CO}_{2}$ (Sun et al., 2011). Although glycine betaine fully replaced glycine, we observed a reduction in growth rate when glycine betaine was supplied as a sole glycine source. Tripp et al. (2009) previously reported that large amounts of glycine betaine had unpredictable or deleterious effects on the growth of Ca. P. ubique in natural seawater. We propose that growth rate reduction may be in part due to toxicity resulting from the production of formaldehyde (by the predicted dimethylglycine dehydrogenase, EC:1.5.99.2,
SAR11_1253) and hydrogen peroxide (by the predicted sarcosine oxidase, EC:1.5.3.1; for genes, see Sun et al., 2011) during glycine betaine catabolism.

We also report the new finding that $C a$. P. ubique partially utilized glycolate to meet its glycine requirement. Glycolate is commonly formed by phytoplankton as a result of photorespiration (Leboulanger et al., 1994, 1997, 1998; Schnitzler Parker et al., 2004; Bertlisson et al., 2005). In E. coli, carbon from glycolate is assimilated into biomass after it is oxidized to glyoxylate by the glycolate oxidase ( $g l c D E F)$ (Pellicer et al., 1996, 1999). Glyoxylate is then condensed with acetyl-CoA by the malate synthase $\left(g l_{c} B\right)$ to form the tricarboxylic acid cycle intermediate malate (Pellicer et al., 1996). In $C a$. P. ubique, genes encoding the glycolate oxidase are found in a putative operon with a pyridoxalphosphate-dependent aminotransferase, annotated as an aspartate aminotransferase ( $a s p C$ ), but separate from the malate synthase gene (Figure 5). Previously, Tripp et al. (2009) had proposed that this aminotransferase produces glycine from glyoxylate, but, working with natural seawater media, were unable to demonstrate replacement of glycine by glycolate to validate this hypothesis.

Results presented here help resolve an enigmatic arrangement of glycine-activated riboswitches associated with genes of the glyoxylate cycle and glycine catabolism. Ca. P. ubique has genes for the proteins required to channel glycolate into the tricarboxylic acid cycle where it can be assimilated into biomass or oxidized ( $g l_{C D E F}$ and glcB; Tripp et al., 2009). In $C a$. P. ubique, a glycine-activated riboswitch is located in a very unusual position upstream of the glcB coding sequence, and a second glycineactivated riboswitch is located in a common arrangement, upstream of gCVT, where it functions to regulate glycine cleavage to $\mathrm{CO}_{2}$ and $\mathrm{NH}_{4}^{+}$. It is now apparent that this unusual configuration of two riboswitches results in glycine concentrations regulating the fate of glyoxylate, as illustrated in Figure 5. We postulate that when intracellular glycine concentrations fall too low, the switch on glcB closes, shunting glycolate through glyoxylate to form glycine. When intracellular glycine concentrations are ample, the glyoxylate bypass opens to channel glycolate-derived carbon into the tricarboxylic acid cycle. We attribute the observation that glycolate did not support as high a cell yield as glycine (Table 3) to its dual role in these pathways. This model also helps explain why $C a$. P. ubique does not respond vigorously to acetate addition; the glyoxylate bypass, which in most cells is used for acetate assimilation, has been recruited to functions that are adaptive to the ocean environment.

One of the mysteries yet to be fully explained is the growth of Ca. P. ubique cells to $10^{6}$ cells $\mathrm{ml}^{-1}$ in the absence any additional carbon compounds except vitamins. We determined the maximum amount of methionine, glycine and pyruvate carried 

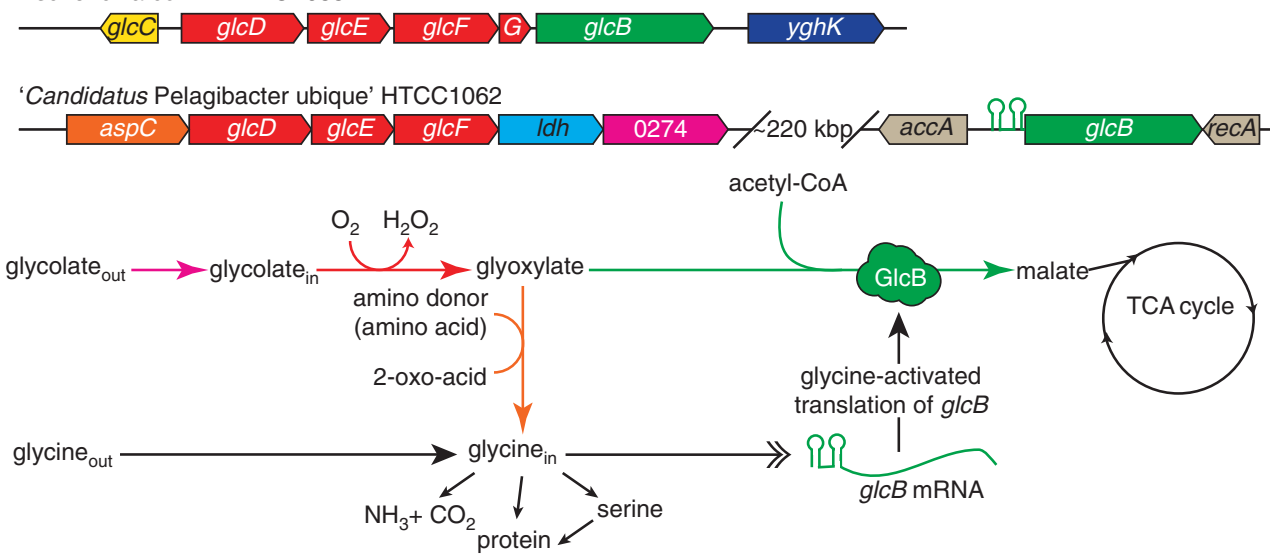

Figure 5 Glycolate assimilation gene organizations in E. coli and Ca. P. ubique. Reaction arrows are colored by the genes predicted to catalyze the reaction. Green stem-loop images represent the glycine-activated riboswitch (Tripp et al., 2009). Gene annotations are as described in NCBI, however, we predict the reaction catalyzed by AspC to be as described in the figure. accA, acetyl-CoA carboxylase; $a s p C$, probable aspartate transaminase; glcC, DNA-binding transcriptional dual regulator, glycolate-binding; glcD, glycolate oxidase subunit, FAD-linked; glcE, glycolate oxidase, FAD-binding subunit; glcF, glycolate oxidase, iron-sulfur subunit; $G$, glcG; Putative glc operon gene, function unknown; glcB, malate synthase G; recA, recombinase A; yghK, glycolate transporter; ldh; probable 2-hydroxyacid dehydrogenase; 0274, SAR11_0274; major facilitator superfamily transporter, possible sugar-phosphate transporter; TCA, tricarboxylic acid.

over with the source inoculum to be 500, 500 and $156 \mathrm{pm}$, respectively. Based on the calculated percell glycine and pyruvate requirement (regression lines in Figure 3), and the previously published sulfur requirement (Tripp et al., 2008), we conclude that the carryover of these nutrients does not sufficiently explain the growth of the negative controls observed in Figures 2 and 3. One alternative explanation for this growth is that $C a$. P. ubique is able to utilize the carbon and sulfur originating from one or more of the vitamins, vitamin degradation products or traces of contaminating carbon in the vitamin stocks. We tested this and found that $C a$. P. ubique responded in a dose-dependent manner to increasing amounts of freshly prepared vitamins (Supplementary Figure S4). It is not clear whether $C a$. P. ubique can utilize the vitamins themselves for growth or if the vitamins enable more efficient use of other traces of contaminating carbon in AMS1. Regardless of the source of the contaminating nutrients, we show that maximum cell densities are two orders of magnitude greater when methionine, glycine and pyruvate are added to the medium.

Metabolic reconstruction has shown Ca. P. ubique's unusual requirement for a balanced supply of organic matter is a consequence of streamlining selection for minimal genome size and metabolic simplicity (Figures 1 and 5; Tripp et al., 2008, 2009; Schwalbach et al., 2010). We speculate that the unusual arrangement of central metabolism in Ca. P. ubique is adaptive not only because it is small and simple, and therefore requires fewer nutrients to replicate, but also because it is suited to planktonic environments where the flux of labile dissolved organic matter is low but continuous most of the time. In addition to the potential supply of pyruvate from glycolysis in some strains, pyruvate and its precursors oxaloacetate and glyoxylate are common metabolic intermediates in other organisms and also are formed by the photooxidation of dissolved organic matter (Kieber and Mopper, 1987; Kieber et al., 1989; Mopper et al., 1991; Moran and Zepp, 1997; Obernosterer et al., 1999). Taurine, a compound produced by both phytoplankton and animals (Huxtable, 1992), also substituted for pyruvate, but at greatly reduced efficiency. Previously it was shown that the $C a$. P. ubique glycine requirement could be met by glycine or serine, which are found in seawater at nanomolar concentrations (Tripp et al., 2009). We also found that the common osmolyte glycine betaine and the photorespiration product glycolate could serve as precursors for glycine biosynthesis. Glycolate is produced by oxygenic phototrophs when they become carbon limited-including both eukaryotic phytoplankton (Leboulanger et al., 1997, 1998; Schnitzler Parker et al., 2004) and marine cyanobacteria (Bertlisson et al., 2005) - the dominant marine phototrophs in temperate and tropical oceans. Tripp showed previously that either methionine or 3-dimethylsulphoniopropionate, a phytoplankton osmolyte, could meet the Ca. P. ubique requirement for organosulfur (Gage et al., 1997; Tripp et al., 2008). Therefore, the results of this study suggest that $C a$. P. ubique has evolved to efficiently use a combination of ubiquitous, low molecular weight metabolites produced by phytoplankton, or resulting from the photooxidation of dissolved organic carbon, which may partially explain its high abundance in the euphotic zone.

A number of definitions have been proposed for the term 'oligotroph' based on optimal and inhibitory nutrient concentrations (reviewed in Schut et al., 1997). These definitions do not easily fit the metabolic behaviors being observed in the 
experiments presented here. The observation that alanine, derived from pyruvate or its precursors, is required for cell division (Figure 4, Supplementary Figures S2 and S3), but that large amounts of alanine adversely affect growth (Table 2), is an example of a deleterious imbalance caused by the presentation of a metabolic substrate to cells at either unnatural concentrations or in unnatural combinations. Unusual nutrient requirements, together with cryptic patterns of nutrient substitution and inhibition, present the experimentalist with a complex problem. This problem can be solved by the stepwise process of metabolic reconstruction coupled with experimentation if a defined medium is available. Although this approach is time consuming (especially with slow-growing cells, such as Ca. P. ubique), it has been successfully applied in other systems (Renesto et al., 2003). The capacity of $\mathrm{Ca}$. P. ubique for growth with the ambient concentrations of organic matter found in autoclaved seawater (Rappé et al., 2002), and in mineral salts without added carbon (Figure 2, Supplementary Figure S4) are ample evidence of the adaptation of these cells to growth at low nutrient concentrations. More importantly, members of the SAR11 clade are the most successful chemoorganoheterotrophs in oligotrophic ocean systems. Therefore, although Pelagibacter defies conventional definitions of the term 'oligotroph' because it can tolerate some compounds at relatively high concentrations, it clearly conforms to the concept of oligotrophy.

Metabolic reconstruction in silico results in metabolic models that are subject to uncertainties that can only be resolved by studying the physiology and metabolism of cells in vitro. The defined medium presented here for $C a$. P. ubique, provides a platform from which such controlled experiments can occur. Ca. P. ubique and other cells with streamlined metabolism are particularly challenging to model because of uncertainties arising from the loss of genes that function in canonical pathways (Figure 1). For instance, the requirements for glycine and alanine were not evident from the initial genome analysis of $\mathrm{Ca}$. P. ubique (Giovannoni et al., 2005). In addition, the hypothesis that pyruvate could serve as the sole carbon precursor for both biosynthesis and energy production was not predicted by previous metabolic models. Uncommon gene arrangements also complicate the interpretation of metabolic models in Ca. P. ubique (Figure 5). In E. coli, the genes coding for proteins required for the assimilation of carbon from glycolate are found at a single locus and are transcribed to a polycistronic message. In Ca. P. ubique, the same genes are physically separated from one another-but their functions are linked through the metabolic intermediate glycine (Figure 5). Experiments with cultures growing on a defined medium are an important step in the refinement of metabolic models such as the one presented in Figures 1 and 5.
The original success of dilution to extinction approaches was founded on the principle that if cells could be detected and cultured at low concentrations, on low nutrient media, their physiological responses to specific nutrient additions could be studied in subsequent experiments. The results presented in Tables 2 and 3 , in light of the previously reported metabolic abilities of Ca. P. ubique (Tripp et al., 2009; Schwalbach et al., 2010), highlight one of the challenges associated with cultivating specialist oligotrophic organisms. Our results suggest that perhaps the largest obstacle to overcome in the cultivation of marine oligotrophs is the specific, unusual and often combinatorial or conditional nutrient requirements. There is growing evidence that a number of abundant microbial plankton species that are not yet cultivated, or are cultivated but difficult to propagate, are similar to Ca. P. ubique in that they are abundant, small cells that contain relatively small genomes $(<2.0 \mathrm{Mbp})$ (Giovannoni et al., 2008; Dupont et al., 2011; Santoro and Casciotti, 2011). The success of cultivating $C a$. P. ubique on artificial media relied on a targeted, minimal combination of nutrients deduced from metabolic reconstruction from a sequenced genome. If, as is likely, such requirements are common among organisms with streamlined genomes, it is hoped that this approach may serve as a blueprint for the cultivation of other important taxa that are difficult to grow in the laboratory.

\section{Acknowledgements}

This article is dedicated to the memory of Dr Craig D Sandgren. Support for this study came from an investigator award from the Gordon and Betty Moore Foundation's Marine Microbiology Initiative. We thank H James Tripp, Kimberly Halsey, Ben Temperton and Cameron Thrash for discussions and critical review of the manuscript.

\section{References}

Bellion E, Tan F. (1987). An NAD+-dependent alanine dehydrogenase from a methylotrophic bacterium. Biochem J 244: 565-570.

Bertlisson S, Berglund O, Pullin M, Chisholm S. (2005). Release of dissolved organic matter by Prochlorococcus. Vie et Milieu 55: 225-232.

Caballero F, Cardenas J, Castillo F. (1989). Purification and properties of L-alanine dehydrogenase of the phototrophic bacterium Rhodobacter capsulatus E1F1. J Bacteriol 171: 3205-3210.

Connon SA, Giovannoni SJ. (2002). High-throughput methods for culturing microorganisms in very-lownutrient media yield diverse new marine isolates. Appl Environ Microbiol 68: 3878-3885.

Dufresne A, Salanoubat M, Partensky F, Artiguenave F, Axmann I, Barbe V et al. (2003). Genome sequence of the cyanobacterium Prochlorococcus marinus SS120, 
a nearly minimal oxyphototrophic genome. Proc Nat Acad Sci USA 100: 10020-10025.

Dunne JA, Williams RJ, Martinez ND. (2002). Network structure and biodiversity loss in food webs: robustness increases with connectance. Ecol Lett 5: 558-567.

Dupont CL, Rusch DB, Yooseph S, Lombardo M-J, Richter RA, Valas R et al. (2011). Genomic insights to SAR86, an abundant and uncultivated marine bacterial lineage. ISME J 6: 1186-1199.

Ferrera I, Gasol JM, Sebastián M, Hojerová E, Koblízek M. (2011). Comparison of growth rates of aerobic anoxygenic phototrophic bacteria and other bacterioplankton groups in coastal mediterranean waters. Appl Environ Microbiol 77: 7451-7458.

Fuhrman JA, Hewson I, Schwalbach MS, Steele JA, Brown MV, Naeem S. (2006). Annually reoccurring bacterial communities are predictable from ocean conditions. Proc Natl Acad Sci USA 103: 13104-13109.

Gage DAD, Rhodes DD, Nolte KDK, Hicks WAW, Leustek TT, Cooper AJA et al. (1997). A new route for synthesis of dimethylsulphoniopropionate in marine algae. Nature 387: 891-894.

Giovannoni S, Stingl U. (2007). The importance of culturing bacterioplankton in the 'omics' age. Nat Rev Micro 5: 820-826.

Giovannoni SJ, Hayakawa DH, Tripp HJ, Stingl U, Givan SA, Cho J-C et al. (2008). The small genome of an abundant coastal ocean methylotroph. Environ Microbiol 10: 1771-1782.

Giovannoni SJ, Tripp HJ, Givan S, Podar M, Vergin KL, Baptista D et al. (2005). Genome streamlining in a cosmopolitan oceanic bacterium. Science 309: 1242-1245.

Grote J, Thrash JC, Huggett MJ, Carini P, Landry ZC, Giovannoni SJ et al. (2012). Streamlining and Core Genome Conservation among Highly Divergent Members of the SAR11 Clade. MBio 3: e00252-12.

Huxtable R. (1992). Physiological actions of taurine. Physiol Rev 72: 101.

Keller M, Kiene R, Matrai P, Bellows W. (1999). Production of glycine betaine and dimethylsulfoniopropionate in marine phytoplankton. I. Batch cultures. Mar Biol 135: 237-248.

Kieber D, McDaniel J, Mopper K. (1989). Photochemical source of biological substrates in sea water: implications for carbon cycling. Nature 341: 637-639.

Kieber D, Mopper K. (1987). Photochemical formation of glyoxylic and pyruvic acids in seawater. Mar Chem 21: 135-149.

Kiene RP, Williams LPH. (1998). Glycine betaine uptake, retention, and degradation by microorganisms in seawater. Limnol Oceanogr 43: 1592-1603.

Leboulanger C, Descolas-Gros C, Jupin H. (1994). HPLC determination of glycolic acid in seawater. An estimation of phytoplankton photorespiration in the Gulf of Lions, western Mediterranean Sea. J Plankton Res 16: 897-903.

Leboulanger C, Martin Jézéquel V, Descolas-Gros C, Sciandra A, Jupin HJ. (1998). Photorespiration in continuous culture of Dunaliella tertiolecta (Chlorophyta): relationships between serine, glycine, and extracellular glycolate. J Phycol 34: 651-654.

Leboulanger C, Oriol L, Jupin H, Desolas-Gros C. (1997). Diel variability of glycolate in the eastern tropical Atlantic Ocean. Deep Sea Res I 44: 2131-2139.
Lynch M, Conery JS. (2003). The origins of genome complexity. Science 302: 1401-1404.

Mengin-Lecreulx D, Flouret B, van Heijenoort J. (1982). Cytoplasmic steps of peptidoglycan synthesis in Escherichia coli. J Bacteriol 151: 1109-1117.

Moore L, Coe A, Zinser E, Saito M, Sullivan M, Lindell D et al. (2007). Culturing the marine cyanobacterium Prochlorococcus. Limnol Oceanogr Methods 5: 353-362.

Mopper K, Zhou X, Kieber R, Kieber D, Sikorski R, Jones R. (1991). Photochemical degradation of dissolved organic carbon and its impact on the oceanic carbon cycle. Nature 353: 60-62.

Moran M, Zepp R. (1997). Role of photoreactions in the formation of biologically labile compounds from dissolved organic matter. Limnol Oceanogr 42: 1307-1316.

Morris RM, Rappé MS, Connon SA, Vergin KL, Siebold WA, Carlson CA et al. (2002). SAR11 clade dominates ocean surface bacterioplankton communities. Nature 420: $806-810$.

Neidhardt FC, Bloch PL, Smith DF. (1974). Culture medium for enterobacteria. J Bacteriol 119: 736-747.

Nörtemann B. (1992). Total degradation of EDTA by mixed cultures and a bacterial isolate. Appl Environ Microbiol 58: 671-676.

Obernosterer I, Kraay G, De Ranitz E, Herndl G. (1999). Concentrations of low molecular weight carboxylic acids and carbonyl compounds in the Aegean Sea (Eastern Mediterranean) and the turnover of pyruvate. Aquat Microb Ecol 20: 147-156.

Pellicer M, Fernandez C, Badia J, Aguilar J, Lin E, Baldoma L. (1999). Cross-induction of glc and ace operons of Escherichia coli attributable to pathway intersectioncharacterization of the glc promoter. J Biol Chem 274: 1745-1752.

Pellicer MT, Badia J, Aguilar J, Baldoma L. (1996). glc locus of Escherichia coli: characterization of genes encoding the subunits of glycolate oxidase and the glc regulator protein. J Bacteriol 178: 2051.

Rappé MS, Connon SA, Vergin KL, Giovannoni SJ. (2002). Cultivation of the ubiquitous SAR11 marine bacterioplankton clade. Nature 418: 630-633.

Renesto P, Crapoulet N, Ogata H, La Scola B, Vestris G, Claverie J-M et al. (2003). Genome-based design of a cell-free culture medium for Tropheryma whipplei. Lancet 362: 447-449.

Santoro AE, Casciotti KL. (2011). Enrichment and characterization of ammonia-oxidizing archaea from the open ocean: phylogeny, physiology and stable isotope fractionation. ISME $J$ 5: 1796-1808.

Schnitzler Parker M, Armbrust EV, Piovia-Scott J, Keil RG. (2004). Induction of photorespiration by light in the centric diatom Thalssiosira weissflogii (Bacillariophyceae): molecular characterization and physiological consequences. J Phycol 40: 557-567.

Schut F, Prins RA, Gottschal JC. (1997). Oligotrophy and pelagic marine bacteria: facts and fiction. Aquat Microb Ecol 12: 177-202.

Schwalbach MS, Tripp HJ, Steindler L, Smith DP, Giovannoni SJ. (2010). The presence of the glycolysis operon in SAR11 genomes is positively correlated with ocean productivity. Environ Microbiol 12: 490-500.

Steele JA, Countway PD, Xia L, Vigil PD, Beman JM, Kim DY et al. (2011). Marine bacterial, archaeal and protistan association networks reveal ecological linkages. ISME J 5: 1414-1425. 
Stingl U, Tripp HJ, Giovannoni SJ. (2007). Improvements of high-throughput culturing yielded novel SAR11 strains and other abundant marine bacteria from the Oregon coast and the Bermuda Atlantic Time Series study site. ISME J 1: 361-371.

Sun J, Steindler L, Thrash JC, Halsey KH, Smith DP, Carter $\mathrm{AE}$ et al. (2011). One carbon metabolism in SAR11 pelagic marine bacteria. PLOS ONE 6: e23973.

Teira E, Martinez-García S, Lønborg C, Álvarez-Salgado XA. (2009). Growth rates of different phylogenetic bacterioplankton groups in a coastal upwelling system. Environ Microbiol Rep 1: 545-554.

Tripp HJ, Kitner JB, Schwalbach MS, Dacey JWH, Wilhelm LJ, Giovannoni SJ. (2008). SAR11 marine bacteria require exogenous reduced sulphur for growth. Nature 452: 741-744.
Tripp HJ, Schwalbach MS, Meyer MM, Kitner JB, Breaker RR, Giovannoni SJ. (2009). Unique glycine-activated riboswitch linked to glycine-serine auxotrophy in SAR11. Environ Microbiol 11: 230-238.

Wientjes FB, Nanninga N. (1989). Rate and topography of peptidoglycan synthesis during cell division in Escherichia coli: concept of a leading edge. J Bacteriol 171: $3412-3419$.

Williams T, Ertan H, Ting L, Cavicchioli R. (2009). Carbon and nitrogen substrate utilization in the marine bacterium Sphingopyxis alaskensis strain RB2256. ISME J 3: 1036-1052.

Zigler JS, Lepe-Zuniga JL, Vistica B, Gery I. (1985). Analysis of the cytotoxic effects of light-exposed HEPES-containing culture medium. In Vitro Cell Dev Biol 21: 282-287.

Supplementary Information accompanies the paper on The ISME Journal website (http://www.nature.com/ismej) 